\title{
Investigate The Factors Affecting Dividend Policy in Listed Firms on Tehran Stock Exchange
}

\author{
Amir Mohammad Hooshyar ${ }^{1,2}$, Mir FarhadSadigh Mohammadi ${ }^{3 *}$, \\ Adel Shah Valizadeh ${ }^{1,2}$ \\ ${ }^{I}$ Department ofAccounting, Science and Research Branch, Islamic Azad University, Ardabil, Iran ${ }^{l}$ \\ ${ }^{2}$ Department of Accounting, Ardabil Branch, Islamic Azad University, Ardabil, Iran \\ ${ }^{3}$ Department of Management and Accounting, Khalkhal Branch, Islamic Azad University, Khalkhal, Iran
}

\begin{abstract}
One of the most controversial topics in the field of financial literature is dividend policy. So, the dividend is one of the issues that has been attracted the attention of financial analysts and investors. In this study, we tried to examine the factors affecting dividend policy based on panel data method of listed firmson Tehran Stock Exchange. For this reason,firmslisted on Tehran Stock Exchange during the years 2009 to 2014, with systematic deletion method and by considering inherent limitations in this field have been screened, and the number of remaining firms to test research hypotheses were 106 firms in terms of 630 observation. The results showed that, the current ratio and financial leverage have a significant and reverse effect on dividend policy in listed firms on Tehran Stock Exchange. Profitability variable has a positive and significant impact on dividend policy in listed firms on Tehran Stock Exchange, and firm size variable doesn't have a negative and significant impact on dividend policy on listed firms on Tehran Stock Exchange.
\end{abstract}

Keywords: dividend policy, firm size, profitability, current ratio

\section{Introduction}

Dividend policy is one of the most important issues in financial management; the dividend represents major cash payments of firms and it's one of the most important options and decisions for managers. The manager must decide how much of the profits should be allocated and how much should be again invested in the firm in the form of retained earnings (Chay, 2009). Although dividend payments may directly benefited shareholders, one of the growth opportunities will be affected by firm's ability to accumulate profits and by dividend policy (Bashiri, 2013). In compiling dividend policy, capital structure of the firm should be maintained. Therefore, considering flexibility in financing is very important. The flexibility in financing means, firms to a certain extent through borrowing can finance; otherwise it will increase the firm's debt ratio and financial risk.A firm that wants to compliance flexibility in finance, considers the dividend policy. In that case, only a relatively small percentage of the profit in firm, is divided between shareholders (Banimahdi\&Asghari, 2011).

Profit is one of the most important concepts in accounting and finance, which makes dividend policy important in management. Dividend policy, is one of the short-term strategies through which performance of firm is evaluated (Wigand, 2009). Dividend policy, is a policy which forms based on the amount of dividend, the accumulated amount, rewards of the board, the date of payment, financing method and other related topics are compiled and presented to the general meeting of shareholders. Dividend policy has been offered as one of the most controversial issues in financial studies. So that, it has attracted the attention of economists in the current century and in more than five recent decades and, so it's the topic of comprehensive theoretical models and empirical studies (Shahnazarian, 2006).

Division of profitcanbe discussed from two important aspects: from one aspect, it is an effective factor in investments of firms. The more profit division, the company's internal resources for the implementation of investment projects will be less and need for more funding from outside of the firm becomes more.Thesefactors could affect the firm's stock price in the future (Dennis, 2008). On the other hand, many shareholders want to divide cash profit. So managers (aimed at maximizing shareholder wealth) should always take a balance between different interests of shareholders to keep profitable opportunities for investing and to pay required cash dividend of some shareholders (Anil 2008). So, division of profit that will be taken by the manager of the firm, is very sensitive and important. Private entities can use their annual net profit to dividend payments of shareholders or their funds can be used for other purposes, including repayment of debts or financing for new investments. Increase of dividends will increase more payment of private entities' cash to shareholders. If the management doesn't intend to provide paid dividends through the use of assets or increase of debts, they should issue and publish additional shares, for providing the necessary funds to pay dividends; so absolute change of dividend distribution policy simultaneously can alter the amount of dividends and the amount 
resultingfromselling of new shares; but always it is possible that, firms changes may occur in several policies of private units. For example, firms may reduce dividends and respective funds will be used to develop its own investments (a combination of dividend distribution policy changes and changes in investment policy), and from the place of these funds will repay part of its debt (a combination of stock distribution policy change and financial structure change). In this manner it can be said that, there is a close relationship between the distribution of dividends, investment and financing (Alizade, 2001).

\section{The main hypothesis}

Financial ratios, have a significant effect on dividend policy in listed firms on Tehran Stock Exchange.

\section{Secondary hypothesis}

1. Financial leverage, has a significant effect on dividend policy in listed firms on Tehran Stock Exchange.

2. Current ratio has a significant effect on dividend policy in listed firms on Tehran Stock Exchange.

3. Profitability has a significant effect on dividend policy in listed firms on Tehran Stock Exchange.

4. The firm size has a significant effect on dividend policy in listed firms on Tehran Stock Exchange.

\section{Methodology}

Statistical population of study was collected with systematic deletion method and by considering inherent limitations in this field have been screened, and the number of remaining firms to test research hypotheses were 106 firms in terms of 630 observation. For data analysis, Excel software and statistical software of Eviews 7 will be used.

por $_{i t}=$ Representative of dividend policy criteriain an i firm at the time of $t$

$\mathrm{Lev}_{\mathrm{it}}=$ Representative of financial leverage of firm in an i firm at the time of $\mathrm{t}$

Financial leverage $=$ all debts $/$ total assets

$\mathrm{Cr}_{\text {it }}=$ Representative of current ratio criteria in an $\mathrm{i}$ firm at the time of $\mathrm{t}$

Current ratio $=$ current asset $/$ current debt

$\mathrm{Roa}_{\text {it }}=$ Representative of profitability criteria in an $\mathrm{i}$ firm at the time of $\mathrm{t}$

Ratio of profitability $=$ net profit $/$ total of assets

Size $_{i t}=$ Representative of firm size criteria in an i firm at the time of $t$

Firm size is obtained from the logarithm of total assets.

$\operatorname{Ros}_{i t}=$ Representative of return in sale criteria in an i firm at the time of $t$

Return in sale $=$ net sale $/$ total sale

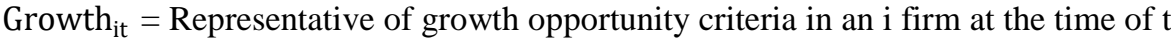

Growth opportunity $=$ Book value of equity - (total assets + market value) $/$ total of assets

$\varepsilon_{\text {it }}=$ indicator of disturbing sentence

Model: dividend policy is a function of financial leverage, current ratio, profitability, size and control variables of return on sales and firm's growth opportunities, in other words we will have:

$$
\text { pro it }=\beta_{0}+\beta_{1} \operatorname{Lev}_{\text {it }}+\beta_{1} \operatorname{Cr}_{\text {it }}+\beta_{1} \operatorname{Roa}_{\text {it }}+\beta_{1} \operatorname{Size}_{\text {it }}+\beta_{2} \operatorname{Ros}_{\text {it }}+\beta_{3} \text { Growth }_{\text {it }}+\varepsilon_{\text {it }}
$$

III. Hypothesis analysis

Table 1.The results of Dividend Policy Model

\begin{tabular}{|l|l|l|l|}
\hline \multirow{2}{*}{ Variable } & \multicolumn{4}{|l|}{ Second model (dividend policy) } \\
\cline { 2 - 4 } & Coefficients & Statistics of t & p-value \\
\hline Intercept & -0.504 & 4.53 & 0.00 \\
\hline Financial Leverage & -0.17 & -4.32 & 0.00 \\
\hline Current ratio & -0.11 & 2.97 & 0.003 \\
\hline Profitability & 0.220 & -5.26 & 0.00 \\
\hline Size & -0.004 & -0.27 & 0.78 \\
\hline Return in sale & 0.009 & 0.19 & 0.84 \\
\hline Growth opportunity & -0.025 & -4.37 & 0.00 \\
\hline $\mathrm{R}^{2}$ & 0.85 & & \\
\hline $\mathrm{R}^{2}$ Adjusted & 0.82 & \\
\hline F Statistic (P-Value) & $27.46(0.00)$ & \multicolumn{2}{|l}{} \\
\hline Durbin-Watson & 1.92 & \multicolumn{5}{|l}{} \\
\hline
\end{tabular}

Results of the model show the model of dividend policy (POR)is a function of the current ratio (CR), profitability (ROA), firm size (SIZE), financial leverage (LEV), and control variables of return on sale (ROS) and growth opportunities (Growth). Simultaneous effect of current ratio (CR), profitability (ROA), firm size (SIZE), financial leverage (LEV), and control variables of return on sale (ROS) and growth opportunities (Growth)were significant on dividend policyat a confidence level greater than $99 \%$ and it refers to the fact that, regression model isn't false and validity of model's statistics is so high. 
Assuming other conditions remain constant, increase in per unit of current ratio $(\mathrm{Cr})$, reduces dividend policy criteria (POR) about 0.11 unit. The respective effect is also confirmed at confidence level of 5\%. And assuming other conditions remain constant, increase in each unit of financial leverage index (LEV), reduces dividend policy criteria (POR) about 0.17 unit. The respective effect is also confirmed at confidence level of $5 \%$. Also by assuming other conditions remain constant, increase in per unit of profitability index, increases dividend policy index (POR) about 0.220 unit. The respective effect is not rejected even at $5 \%$ confidence level, in other words it's significant, and statistically firm size variable does not have a significant effect on dividend policy.This effect is rejected at 5\% significance level.

Regarding coefficients of control variables in this model, it can be said that, assuming all other conditions remain constant, with increase in each unit of growth opportunities index, dividend policy criteria is reduced about 0.025 unit and respective effect is not rejected even at $5 \%$ confidence level, while with increase in each unit of financial leverage in firm, return on sales criteria (ROS) increases about 0.22 unit and the respective effect is significant. While return on sales index, has no impact on financial flexibility.

\section{Conclusion and Recommendations}

According to the results obtained from testing hypothesis, financial leverage has a significant effect on dividend policy in listed firms on Tehran Stock Exchange, so respective hypothesis is confirmed; in other words, financial leverage has a significant and reverse effect on dividend policy. According to the relevant previous studies it was observed that, in the field of profit distribution almost all successful firms pay dividends and financial managerspay special attention to the distribution of profit. Distribution of profit also affects share value, in order to maximize shareholder wealth, managers should always take a balance between different interests of shareholders to keep profitable opportunities for investing and to pay required cash dividend of some shareholders. Therefore, making decisions about dividend by managers, is very sensitive and important; so dividend in firms may partly be pleasant, and if the firm gets out of the desirable limits of dividend, stock price will react fundamentally and negatively. Thus there is a conflict between desire of shareholders to distribute profit and manager's need to pay debts. According to the results obtained from testing hypothesis, profitability has a significant effect on dividend policy in listed firms on Tehran Stock Exchange, so the respective hypothesis is confirmed. So according to the test hypothesis, profitability has a significant impact on dividend policy. Distributing profit can be used as factors to monitor and evaluate management performance by shareholders. Performance of manager is desirable and good for shareholders when maintaining the efficiency of various factors on the firm's performance, by increasing the profitability ability of firms, increasing corporate value and performing projects with positive net present value, they can add on shareholders wealth. So the relationship between dividends and earnings per share, represents dividend policy of the firm. Dividend policy can attract new shareholders to the company. Dividend signaling hypothesis indicate that, change in DPS will have some information about firm's future profitability. So, company managers to convey a clear view of profitability and positive cash flows attempt to increase dividend. According to the results obtained from testing hypothesis, firm size has a significant effect on dividend policy in listed firms on Tehran Stock Exchange, so the respective hypothesis is not confirmed. Firm size could represent a competitive advantage. Since gaining more market share, needs to produce and sell more, therefore having adequate financial resources and firm's larger size can help to produce more and spend more marketing costs to create competitive advantages. Firm size is indicative of firm's overall risk. More financial power can reduce the overall risk, because larger firms are more exposed to public safety,andsize determines the amount of work the firm does. Also,firm size can show the informational efficiency. Usually larger firms attract more attention from analysts and investors, so larger firms have more efficient process accounting information.

\section{References}

[1] Bashiri, F. \&Jalali, A. (2013). Investigating the effect of maintained liquid assets and financial flexibility on abnormal stock returns at Companies listed on Tehran Stock Exchange, third year, Issue 10, 35-52.

[2] Banimahd, B \&Asghari, A. (2011).Investigating the effect of firm leverage on dividend policy of listed companies on Tehran stock exchange, financial knowledge of analyzing securities, Issue I, summer 2011.

[3] Shahnazarian, A.(2006). Investigating correlation between dividend and cash flow in companies listed on Tehran Stock Exchange, MS Thesis, Faculty of Management and Accounting, ShahidBeheshti University.

[4] Alizadeh, A. (2001). Investigating the correlation between dividends and changes in cash flows, MS Thesis, School of Management, Tehran University.

[5] Anil K. \& S. Kapoor. (2008). Determinants of Dividend Payout Ratios- A Study of Indian Information Technology Sector, International Research Journal of Finance and Economics, Vol.15 pp.63-71.

[6] Chay, J.B. \&JungwonSuh.(2009). Payout Policy and Cash-flow Uncertainty, Journal of Financial Economics, Vol.93 pp.88-107.

[7] Denis, David J. \& Igor Osobov. (2008). Why Do Firms Pay Dividends?

[8] International Evidence on the Determinants of Dividend Policy, Journal of Financial Economics, Vol.89 pp.62- 82.

[9] Weigand, Robert A. \& H. Kent Baker (2009). Changing Perspectives on Distribution Policy, Managerial Finance, Vol.35 No.6 pp.479-492 